hypercapnia there is an upper blood pressure limit beyond which autoregulation fails and cerebral blood flow increases (Ekström-Jodal et al., 1971). Such an upper limit of autoregulation was found in four of our patients but seemed unrelated to their $\mathrm{PaCO}_{2}$. No evidence of arteriolar spasm at high pressure was found in any of the patients studied. The 5 to 10 minutes of steady state maximum blood pressure should be ample time for autoregulation to operate, since this mechanism is known to be fully effective within 1 minute after blood pressure changes (Symon et al., 1971). The fact that a similar increase in cerebral blood flow was found in one normotensive patient with a mean arterial blood pressure above $120 \mathrm{~mm} \mathrm{Hg}$ suggests that the phenomenon is not caused by hypertensive vascular disease per se; it seems more likely that an upper limit of autoregulation is present in all persons and that even this upper limit is raised in hypertension.

None of our patients had symptoms during the short period of increased blood pressure. A sustained increase in blood pressure with hyperperfusion of the brain would be expected to cause exudation of plasma through the walls of arterioles and capillaries, this in turn giving rise to focal cerebral oedema, compression of capillaries, a decrease in cerebral blood flow, and the clinical picture of acute hypertensive encephalopathy (Byrom, 1969; Lassen and Agnoli, 1972). The initial event in this pathogenetic chain has been termed a "break-through of autoregulation" (Lassen and Agnoli, 1972).
On a smaller scale similar phenomena may occur during sleep hypercapnia, causing the well known morning headache of the hypertensive patient.

Further investigations on the pathogenesis of hypertensive encephalopathy probably must rely on animal experiments with repeated measurements of cerebral blood flow with direct methods at very high blood pressure.

\section{References}

Byrom, F. B. (1954). Lancet, 2, 201.

Byrom, F. B. (1969). The Hypertensive Vascular Crisis. London, Heineman. Ekström-Jodal, B., Häggendal, E., Linder, L. E., and Nilsson, N. J. (1971). European Neurology, 6, 6 .

Fazekas, J. F. (1966). American fournal of Cardiology, 17, 608

Finnerty, F. A., Witkin, L., and Fazekas, J. F. (1954). fournal of Clinical Investigation, 33, 1227 .

Finnerty, F. A. (1972). American fournal of Medicine, 52, 672.

Folkow, B. (1971). Clinical Science, 41, 1 .

Harper, A. M., and Glass, H. I. (1965). fournal of Neurology, Neurosurgery and Psychiatry, 28, 449.

Holmgren, A., and Pernow, B. (1959). Scandinavian fournal of Clinical and Laboratory Investigation, $11,143$.

Lassen, N. A. (1959). Physiological Reviews, 39, 183

Lassen, N. A., and Agnoli, A. (1972). Scandinavian fournal of Clinical and Laboratory Investigation, 30, 113.

Lennox, W. G., and Gibbs, E. L. (1932). Fournal of Clinical Investigation, 11,1155 .

Olesen, J. (1972a). Archives of Neurology. In press.

Olesen, J. (1972b). Neurology, 22, 978.

Symon, L., Iteld, K., and Dorsch, N. W. C. (1971). European Neurology, 6,

\title{
Use of 4\% Chlorhexidine Detergent Solution (Hibiscrub) and Other Methods of Skin Disinfection
}

\author{
E. J. L. LOWBURY, H. A. LILLY
}

of bacteria on skin sampling. Unlike this "two-phase" disinfection, the application for $\mathbf{3 0}$ minutes of compresses soaked in $10 \%$ aqueous povidone iodine or in $\mathbf{0 . 5} \%$ aqueous chlorhexidine digluconate did not cause a greater reduction in skin flora than that obtained by the conventional two minutes' application on gauze of $0.5 \%$ chlorhexidine in $\mathbf{7 0} \%$ ethanol.

Chlorocresol $(0.3 \%)$ liquid soap (the base used for Ster-Zac liquid hexachlorophane soap) caused a mean reduction of skin flora when used for hand washing of $29 \%$ after one application and $72 \%$ after six applications spread over two days. This formulation, though less active and more variable as a detergent skin antiseptic than chlorhexidine, hexachlorophane, or povidone iodine detergent preparations, is an inexpensive disinfectant soap which could be useful in catering establishments. Alcoholic cetrimide applied as for disinfection of an operation site caused a reduction of skin flora greater than that shown by aqueous cetrimide but comparable to that shown by $70 \%$ ethyl alcohol in previous experiments.

\section{Introduction}

M.R.C. Industrial Injuries and Burns Unit, Birmingham Accident Hospital, Birmingham B15 1NA

E. J. L. LOWBURY, D.M., F.R.C.PATH., Bacteriologist and Honorary Director, Hospital Infection Research Laboratory

H. A. LILLY, F.I.M.L.T., Senior Technical Officer

Several developments in the technique of skin disinfection, including the use of a $0.75 \%$ chlorhexidine detergent solution for the hands, were recently reported from this unit (Lilly and Lowbury, 1971). Since then a more concentrated chlorhexidine preparation, Hibiscrub, has been introduced. In this paper we 
TABLE I-Disinfection of Hands: Reduction in Bacterial Counts from Hand Washings after Disinfection, Expressed as Percentage of Initial Count

\begin{tabular}{|c|c|c|c|c|c|c|c|c|}
\hline \multirow[t]{2}{*}{$\begin{array}{c}\text { Replicate } \\
\text { Experiments }\end{array}$} & \multicolumn{2}{|c|}{$\begin{array}{c}\text { (A) } \\
4 \% \\
\text { Chlorhexidine } \\
\text { Detergent Preparation } \\
\text { (Hibiscrub) }\end{array}$} & \multicolumn{2}{|c|}{$\begin{array}{c}\text { (B) } \\
0.75 \% \\
\text { Chlorhexidine } \\
\begin{array}{c}\text { Detergent Preparation } \\
\text { (Dermofax) }\end{array}\end{array}$} & \multicolumn{2}{|c|}{$\begin{array}{c}\text { (C) } \\
\text { Povidone } \\
\text { Iodine "Scrub" } \\
\text { (Disadine) }\end{array}$} & \multicolumn{2}{|c|}{$\begin{array}{c}\text { (D) } \\
\text { Bar Soap } \\
\text { (Control) }\end{array}$} \\
\hline & $\begin{array}{c}\text { After } 1 \\
\text { Application }\end{array}$ & $\begin{array}{c}\text { After } 6 \\
\text { Applications }\end{array}$ & $\begin{array}{c}\text { After 1 } \\
\text { Application }\end{array}$ & $\begin{array}{c}\text { After } 6 \\
\text { Applications }\end{array}$ & $\begin{array}{c}\text { After 1 } \\
\text { Application }\end{array}$ & $\begin{array}{c}\text { After } 6 \\
\text { Applications }\end{array}$ & $\begin{array}{c}\text { After } 1 \\
\text { Application }\end{array}$ & $\begin{array}{c}\text { After } 6 \\
\text { Applications }\end{array}$ \\
\hline $\begin{array}{l}1 \\
2 \\
3 \\
4 \\
5 \\
6 \\
7 \\
8\end{array}$ & $\begin{array}{l}\text { G.S. } 71 \cdot 3 \\
\text { S.D. } 89 \cdot 2 \\
\text { A.K. } 89 \cdot 3 \\
\text { B.D. } 94 \cdot 1 \\
\text { E.R. } 76 \cdot 9 \\
\text { B.G. } 93 \cdot 1 \\
\text { S.F. } 94 \cdot 2 \\
\text { A.B. } 85 \cdot 8\end{array}$ & $\begin{array}{l}99.8 \\
99.1 \\
99.4 \\
98.5 \\
99.2 \\
98.1 \\
99.9 \\
99.8\end{array}$ & $\begin{array}{l}\text { A.K. } 40.5 \\
\text { B.D. } 76.1 \\
\text { G.S. } 56.0 \\
\text { S.D. } 45.8 \\
\text { B.G. } 72 \cdot 1 \\
\text { S.F. } 64 \cdot 3 \\
\text { A.B. } 36 \cdot 3 \\
\text { E.R. } 52 \cdot 6\end{array}$ & $\begin{array}{l}87.0 \\
96.1 \\
92.1 \\
86.1 \\
94.5 \\
98.1 \\
92.7 \\
87.7\end{array}$ & $\begin{array}{l}\text { B.D. } 64 \cdot 8 \\
\text { G.S. } 83.5 \\
\text { S.D. } 29 \cdot 9 \\
\text { A.K. } 81 \cdot 1 \\
\text { S.F. } 77 \cdot 2 \\
\text { A.B. } 48 \cdot 2 \\
\text { E.R. } 81 \cdot 8 \\
\text { B.G. } 77 \cdot 3\end{array}$ & $\begin{array}{l}97 \cdot 5 \\
99 \cdot 1 \\
99.7 \\
98.4 \\
99 \cdot 2 \\
93.8 \\
98.2 \\
95.5\end{array}$ & $\begin{array}{l}\text { S.D. } 12 \cdot 7 \\
\text { A.K. }-40 \cdot 7^{*} \\
\text { B.D. }-23 \cdot 4^{*} \\
\text { G.S. } 14 \cdot 2 \\
\text { A.B. } 9.0 \\
\text { E.R. } 8 \cdot 8 \\
\text { B.G. } 13 \cdot 0 \\
\text { S.F. } 32 \cdot 5\end{array}$ & $\begin{array}{r}20 \cdot 8 \\
4 \cdot 6 \\
28 \cdot 1 \\
28 \cdot 3 \\
29 \cdot 2 \\
21 \cdot 8 \\
18 \cdot 7 \\
56 \cdot 0\end{array}$ \\
\hline Mean $\%$ reduction & $86.7( \pm 3.0)$ & $99 \cdot 2( \pm 0 \cdot 2)$ & $55 \cdot 5( \pm 5 \cdot 1)$ & $91 \cdot 8( \pm 1 \cdot 6)$ & $68.0( \pm 6.8)$ & $97.7( \pm 0.7)$ & $3 \cdot 3( \pm 8 \cdot 3)$ & $25.9( \pm 5 \cdot 1)$ \\
\hline
\end{tabular}

Initials indicate experimental subjects.

Values indicate increase expressed as percentage of initial count.

Comparison of treatments ( $t$ tests):

(A) and (B), 1 application: $t=5.27, \mathrm{P}<0.001$.

(A) and (B), 6 applications: $t=4.65, \mathrm{P}<0.001$

(A) and (C), 1 application: $t=2.51, P<0.05$

(A) and (C), 6 applications: $t=1.98, \mathrm{P}>0.05$ (not significant).

(B) and (C), 1 application: $t=1.46, \mathrm{P}>0.05$ (not significant).

(B) and (C), 6 applications: $t=3.11, \mathrm{P}<0.01$.

(B) and (D), 1 application: $t=5$ applications: $t=12.3, \quad \mathrm{P}<0.001$.

report comparisons of Hibiscrub with hexachlorophane and iodophor detergent preparations, and assessments of some other methods, including two special techniques for obtaining more intensive disinfection.

\section{Assessment of $4 \%$ Chlorhexidine Detergent Solution (Hibiscrub) for Disinfection of Hands}

\section{PREPARATIONS STUDIED}

The following preparations were compared. (a) Hibiscrub, a $4 \%$ solution of chlorhexidine (Hibitane) digluconate (B.P.) in a detergent base containing $25 \% \mathrm{w} / \mathrm{v}$ Pluronic F87 (a nonionic surfactant described as polyoxy ethylene-polyoxy propylene block polymer) and 3.7\% w/v Ammonyx LO (an amphoteric surfactant, dimethyl lauryl amine oxide). (b) Dermofax, a 0.75\% solution of chlorhexidine digluconate in a detergent base previously described (Lilly and Lowbury, 1971). (c) Disadine scrub, a povidone iodine detergent solution containing $0.75 \%$ available iodine in a base containing an anionic detergent (ammonium salt of sulphated alkyl phenoxy-polyethyleneoxyethanol). (d) Control application-unmedicated bar soap.

\section{METHOD OF ASSESSING DISINFECTION OF HANDS}

As in previous studies (Lowbury et al., 1960, 1963; Lilly and Lowbury, 1971) each preparation was tested on each of a series of volunteers, and a Latin square design was used. Replicate experiments were made, the four subjects in the second experiment being different from those in the first.

The following methods were used for washing hands with Hibiscrub and with povidone iodine surgical scrub. After moistening the hands with water about $7 \mathrm{ml}$ of the solution was poured on to the hands and rubbed systematically over all surfaces of both hands and wrists for two minutes; the hands were then rinsed under running water. With Dermofax, the preparation was rubbed over the dry skin of both hands for one and a half minutes after which water was added to produce a lather for a further half minute, before rinsing. In the control treatment with bar soap and water the hands and wrists were systematically washed for two minutes and rinsed under a tap, as in the treatment with disinfectant-detergent preparations.

Bacterial counts on pour plates were obtained from standard hand samplings taken before and immediately after the first disinfectant and control hand washings and again after the last of five similar hand washings with the same preparations, two on the first and three on the second day. The technique of sampling was the same as that described by Lowbury et al. (1963). The sampling solutions and nutrient agar contained neutralizers for the antiseptics studied ( $1 \%$ Lubrol W, $0.5 \%$ lecithin, $1 \%$ Tween 80 , and $1 \%$ sodium thiosulphate). Tests were made for carry-over of disinfectant to plates showing no growth or scanty growth (Lowbury et al., 1960). An interval of at least seven days was allowed between experiments on subjects to allow a return to the normal level of skin flora.

\section{RESULTS}

The results of the trial are given in table I. Washing with Hibiscrub caused a significantly greater mean immediate reduction $(86.7 \%)$ in bacterial counts from standard skin samplings than was found with Dermofax* $(55.5 \%)$ or with Disadine (povidone iodine) scrub (68.0\%); the reduction found after six disinfectant washes spread over two days was greater with Hibiscrub (99.2\%) than with Dermofax $(91.8 \%)(P<0.01)$ or with Disadine Scrub (97.7\%) (not significant); each of the disinfectant treatments caused a highly significant reduction in bacterial counts from skin samplings compared with the control treatment (soap and water). There was no evidence of carry-over of disinfectant to the culture plates. An analysis of variance: of one of the Latin squares is shown in table II.

TABLB II-Disinfection of Hands (see table I): Analysis of Variance (Experiments 1-4)

\begin{tabular}{|c|c|c|c|c|c|}
\hline $\begin{array}{l}\text { No. of } \\
\text { Applications }\end{array}$ & $\begin{array}{l}\text { Source of } \\
\text { Variance }\end{array}$ & $\begin{array}{l}\text { Sums of } \\
\text { Squares }\end{array}$ & $\begin{array}{l}\text { Degrees of } \\
\text { Freedom }\end{array}$ & $\begin{array}{c}\text { Mean } \\
\text { Squares }\end{array}$ & Significance \\
\hline \multirow[t]{2}{*}{1} & $\begin{array}{l}\text { Experiments } \\
\text { Treatment } \\
\text { Persons } \\
\text { Residual }\end{array}$ & $\begin{array}{r}920 \cdot 3 \\
20191 \cdot 2 \\
522 \cdot 1 \\
3654 \cdot 7\end{array}$ & $\begin{array}{l}3 \\
3 \\
3 \\
6\end{array}$ & $\begin{array}{r}306 \cdot 7 \\
6730 \cdot 0 \\
174 \cdot 0 \\
609 \cdot 1\end{array}$ & $\begin{array}{l}>0.2 \\
<0.01 \\
>0.05\end{array}$ \\
\hline & Total & $25288 \cdot 3$ & 15 & & \\
\hline \multirow[t]{2}{*}{6} & $\begin{array}{l}\text { Experiments } \\
\text { Treatment } \\
\text { Persons } \\
\text { Residual }\end{array}$ & $\begin{array}{r}57.0 \\
17351.9 \\
156.4 \\
226.6\end{array}$ & $\begin{array}{l}3 \\
3 \\
3 \\
6\end{array}$ & $\begin{array}{r}19.0 \\
5783.9 \\
52.1 \\
37.7\end{array}$ & $\begin{array}{l}>0.2 \\
<0.001 \\
>0.2\end{array}$ \\
\hline & Total & 17791.9 & 15 & & \\
\hline
\end{tabular}

* The manufacturers now supply Dermofax containing a higher concentration of chlorhexidine. 
TABLE III-Disinfection of Operation Sites by Compresses, etc.: Reduction in Bacterial Counts from Hand Washings Expressed as Percentage of Initial Count

\begin{tabular}{|c|c|c|c|c|c|c|}
\hline \multirow{2}{*}{\multicolumn{2}{|c|}{ Method of Disinfection }} & \multicolumn{4}{|c|}{ Replicate Experiments } & \multirow{2}{*}{$\begin{array}{c}\text { Mean } \\
o \% \\
\text { Reduction }\end{array}$} \\
\hline & & 1 & 2 & 3 & 4 & \\
\hline $\begin{array}{l}\text { (a) Povidone iodine compress ( } 30 \text { min.) .. } \\
\text { (b) } 0.5 \% \text { Aqueous chlorhexidine compress }(30 \mathrm{~min} .) \\
\text { (c) } 0.5 \% \text { Alcoholic chlorhexidine swabbing ( } 2 \text { min.) } \\
\text { (d) Hibiscrub swabbing ( } 2 \text { min.) } \quad \text {. }\end{array}$ & $\begin{array}{ll}\cdots & \cdots \\
\cdots & \cdots \\
\cdots & \cdots\end{array}$ & $\begin{array}{l}\text { B.D. } 97 \cdot 7 \\
\text { E.V. } 30 \\
\text { S.D. } 82 \cdot 2 \\
\text { B.G. } 42 \cdot 2\end{array}$ & $\begin{array}{l}\text { B.G. } 90 \cdot 9 \\
\text { S.D. } 63 \\
\text { B.D. } 69 \cdot 6 \\
\text { E.V. } 84 \cdot 3\end{array}$ & $\begin{array}{l}\text { S.D. } 90 \\
\text { B.G. } 81 \cdot 3 \\
\text { E.V } 82 \cdot 4 \\
\text { B.D. } 85 \cdot 3\end{array}$ & $\begin{array}{l}\text { E.V. } 74 \cdot 4 \\
\text { B.D. } 76 \cdot 5 \\
\text { B.G. } 89 \cdot 1 \\
\text { S.D. } 72 \cdot 4\end{array}$ & $\begin{array}{l}88 \cdot 3( \pm 4 \cdot 9) \\
62 \cdot 7( \pm 11 \cdot 6) \\
80 \cdot 8( \pm 4 \cdot 1) \\
71 \cdot 1( \pm 10 \cdot 1)\end{array}$ \\
\hline
\end{tabular}

Comparison of methods:

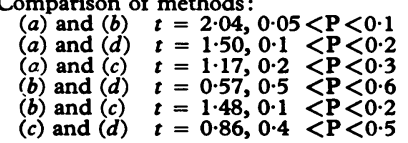

Initials indicate experimental subjects.

\section{Special Methods Designed for More Intensive Disinfection of Operation Sites}

The following studies were made in order to assess methods by which the skin flora might be reduced to a greater degree than it is by the standard methods used for the operation site. Such methods would be indicated before operations on patients with enhanced susceptibility to infection-for example, in immunodeficient subjects or when immunosuppressive drugs are used.

Application of Compresses.-Compresses of povidone iodine applied for 30 minutes have been found highly effective in destroying bacterial spores on the skin (Lowbury et al., 1964b; Drewett et al., 1972). In this study we compared the effectiveness of (a) compresses containing an aqueous solution of $10 \%$ povidone iodine (Disadine) with $1 \%$ available iodine, (b) compresses containing $0.5 \%$ aqueous chlorhexidine digluconate solution, (c) $0.5 \%$ chlorhexidine gluconate in $70 \%$ ethyl alcohol, rubbed on to the skin for two minutes with gauze swabs, and (d) $4 \%$ chlorhexidine detergent solution (Hibiscrub) applied on a swab as with (c).

\section{METHODS}

After a quick "social" wash with bar soap and water, the hands were rinsed, dried on a sterile towel, and sampled for viable counts by a standard hand washing technique, with neutralizers in sampling fluids and culture media (Lowbury et al., 1963). The hands were then rinsed and dried on a sterile towel. In the experiments with compresses, strips of gauze soaked in the antiseptic solutions $(a)$ and $(b)$ were applied over the whole surface of both hands and wrists. After 30 minutes the compresses were removed; the hands were rinsed under running warm water, dried, and sampled again for viable counts. In the experiments with alcoholic chlorhexidine $(c)$, the application of this preparation to the hands was carried out as in routine preoperative disinfection. The $4 \%$ chlorhexidine detergent preparation $(d)$ was applied in the same way for two minutes. Bacteriological sampling of hands before and after application of $(c)$ and $(d)$ was carried out as in treatment groups $(a)$ and (b).

A Latin square design was used, all four methods being used by each of the four experimental subjects. Experiments on subjects were separated by a week or more to allow the normal levels of skin colonization to be restored.

\section{RESULTS}

These are shown in table III. Though the largest mean percentage reduction was $88 \%$ (with povidone iodine compresses) and the smallest (with aqueous chlorhexidine compresses) was $63 \%$, the differences between them and between other pairs did not reach significance levels. Hibiscrub applied on a swab gave a lower mean estimated reduction in bacterial flora of the skin $(71 \%)$ than the same preparation used in washing the hands, as shown in table I (87\%). Thirty minutes' application of compresses did not offer any apparent advantage over a two minutes' application of the same compound rubbed on with gauze swabsfor example, aqueous chlorhexidine compresses in this experiment caused a mean reduction of $63 \%$, compared with a mean reduction of $60 \%$ obtained by rubbing on of $0.5 \%$ aqueous chlorhexidine diacetate with gauze in a previous experiment (Lowbury et al., 1960). The standard method of operating site disinfection with $0.5 \%$ chlorhexidine in alcohol gave a mean reduction of $80 \%$, which was slightly (though not significantly) lower than that given by povidone iodine compresses.

Repeated Use of Detergent Antiseptic Followed by Alcoholic Antiseptic Preparation ("Two-phase" Disinfection).-Lowbury et al. (1964b) showed that $0.5 \%$ alcoholic chlorhexidine applied with friction, as in preoperative preparation of the skin, caused as large a reduction in bacterial flora if the skin had previously been disinfected by repeated washing with a hexachlorophane detergent cream as when the skin had not been thus disinfected; the mean estimated reduction in viable counts from skin after such "two-phase" disinfection was $99.98 \%$ and about half of the subjects on whom such treatment had been carried out showed no detectable bacteria in standard hand wash samplings. It seemed likely that the large reduction in skin bacteria caused by this treatment was due to the use of different methods of application, and possibly also to the use of different antiseptics in the two phases of treatment, the second phase causing a further reduction after an equilibrium had been established on repeated use of the first phase treatment (detergent antiseptic hand washes). The following experiments were made in an attempt to confirm and clarify this mechanism.

\section{METHODS}

Experiment 1.-Subjects who were using disinfectant-detergent preparations three times a day were sampled for viable bacterial counts of hand washings before the first use of the preparation and after the first, third, sixth, ninth, and twelfth hand wash. Experiments were made on four subjects, two each with Hibiscrub and with Disfex (3\% hexachlorophane cream containing a $p$-hydroxybenzoic acid ester as preservative).

Experiment 2.-In this experiment we tested the hypothesis that "two-phase" disinfection depends on a further reduction in the numbers of bacteria on the skin below the equilibrium level, caused by the use of a different vehicle for the antiseptic and a different form of application in the second phase of disinfection. Eight subjects carried out the standard two minutes' hand washing with Hibiscrub on nine occasions, three each on three successive days. Standard samplings for viable counts were made before the first hand wash and again after the ninth hand wash. Four of the subjects were then given, for the second phase, a standard two minutes' skin disinfection with $0.5 \%$ alcoholic chlorhexidine rubbed on with gauze, (Lowbury et al., 1964b). In the four other subjects the second phase of disinfection consisted of a further two minutes' hand wash with Hibiscrub immediately after the sampling which followed the ninth Hibiscrub hand wash. Standard samplings for viable counts were 
made on the eight volunteers immediately after the secondphase disinfection.

Experiment 3.-Further confirmatory studies were made with three different preparations (Hibiscrub, Disfex, and 3\% hexachlorophane liquid soap containing $0.3 \%$ chlorocresol (Ster-Zac)) in the first phase of disinfection, and with $0.5 \%$ alcoholic chlorhexidine, applied for two minutes on gauze swabs, in the second phase. The first phase consisted of three standard hand washes on each of three successive days. Samplings for counts of skin bacteria were obtained by the standard technique before and immediately after the first disinfectant hand wash, after the ninth disinfectant hand wash, and after disinfection with alcoholic chlorhexidine.

\section{RESULTS}

These are shown in table IV. In experiment 1 the estimated mean reduction in skin flora after the first application was greater with Hibiscrub than with Disfex, but the eventual reduction achieved by these two preparations was similar. Though an equilibrium level seemed to be reached after six treatments, the pour plate counts from $1 \mathrm{ml}$ of undiluted washings taken at this stage were very low (between 1 and 3 ). Similar very large reductions to very low counts were obtained with Hibiscrub and with Ster-Zac liquid soap in the first phase of experiment 3, so that the further reduction or elimination of bacteria which were found in phase 2 in all but one of the subjects who were treated with these agents in the second phase had little or no significance; by contrast, after the use of Disfex in phase 1 reductions from 97 to 1,27 to 3 , and 23 to 1 were found in colony-counts of pour plates from undiluted washings taken after phase 2 disinfection.

In experiment 2 (see chart), phase 1 of disinfection (nine washings with Hibiscrub) caused a large estimated mean reduction in skin bacteria (about $99 \%$ ), which was followed by a large further mean reduction (about $95 \%$ ) in the second phase of disinfection when the agent used for this was $0.5 \%$ chlorhexidine in $70 \%$ ethanol; counts per $\mathrm{ml}$ undiluted washings fell from 271 to 1,52 to 9,7 to 0 , and 3 to 0 ; by contrast, when the second phase of disinfection consisted of an immediate further standard hand wash with Hibiscrub there was no further reduction in any subject, and in three there was an increase in estimated skin flora after the "second phase" treatment (from 51 to 138, from 8 to 87 , and from 58 to 91 bacteria per $\mathrm{ml}$ undiluted washings).

\section{Disinfection of Hands by Chlorocresol (0.3\%) in Liquid Soap}

The inclusion by a manufacturer of $0.3 \%$ chlorocresol in liquid hexachlorophane soap was effective in preventing contamination

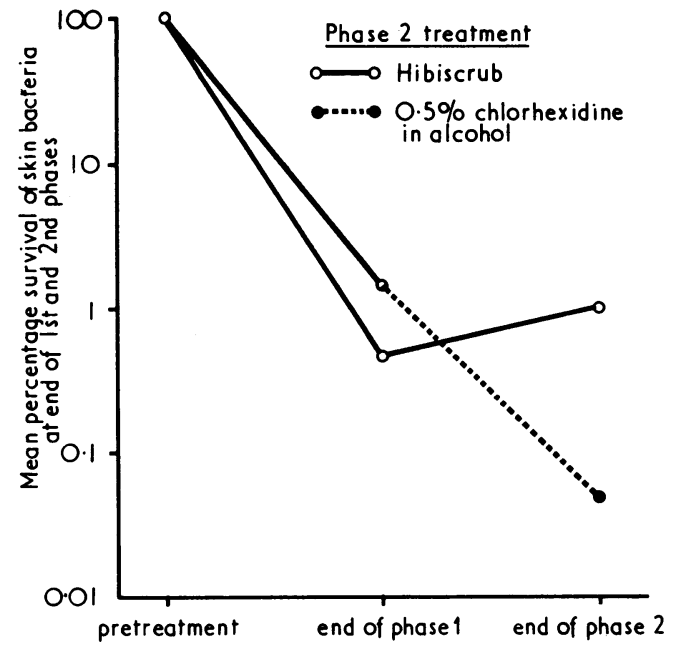

"Two-phase" disinfection of hands: mean percentage survival in hand sample counts after nine standard handwashes with Hibiscrub (the first phase), followed immediately by "second phase" disinfection with alcoholic chlorhexidine or with Hibiscrub; eight subjects were studied, four treated with one and four treated with the other "second phase" preparation.

of the soap by Gram-negative bacilli (Collins and Deverill, 1971). This additive appeared to enhance the skin disinfecting properties of the hexachlorophane soap, and was shown to have an independent skin-disinfectant action in a liquid soap containing $0.3 \%$ chlorocresol but no hexachlorophane (Lilly and Lowbury, 1971).

In this study we compared the skin disinfectant action of the soap base containing $0.3 \%$ chlorocresol with that of a $3 \%$ hexachlorophane detergent cream (Disfex). The techniques of hand washing and hand sampling were the same as in the experiments with Hibiscrub described above, sampling times being immediately before and immediately after the first standard two minutes' hand wash, and the last sampling being after the sixth hand wash, the hands being washed three times on each of two successive days. Five volunteers were used, each using each of the two preparations.

\section{RESULTS}

These are shown in table $\mathrm{V}$. The chlorocresol soap gave smaller reductions in bacterial skin flora after one and after six applications than those obtained with Disfex, and there was more variation between results on different subjects. The mean reduction after six washes with chlorocresol soap ( $72 \%$ ), however, shows that it might be useful in situations where some disinfection is desirable but the most intensive disinfection is not essential-for example, for catering staff.

TABLE IV-“Two-phase" Disinfection of Skin

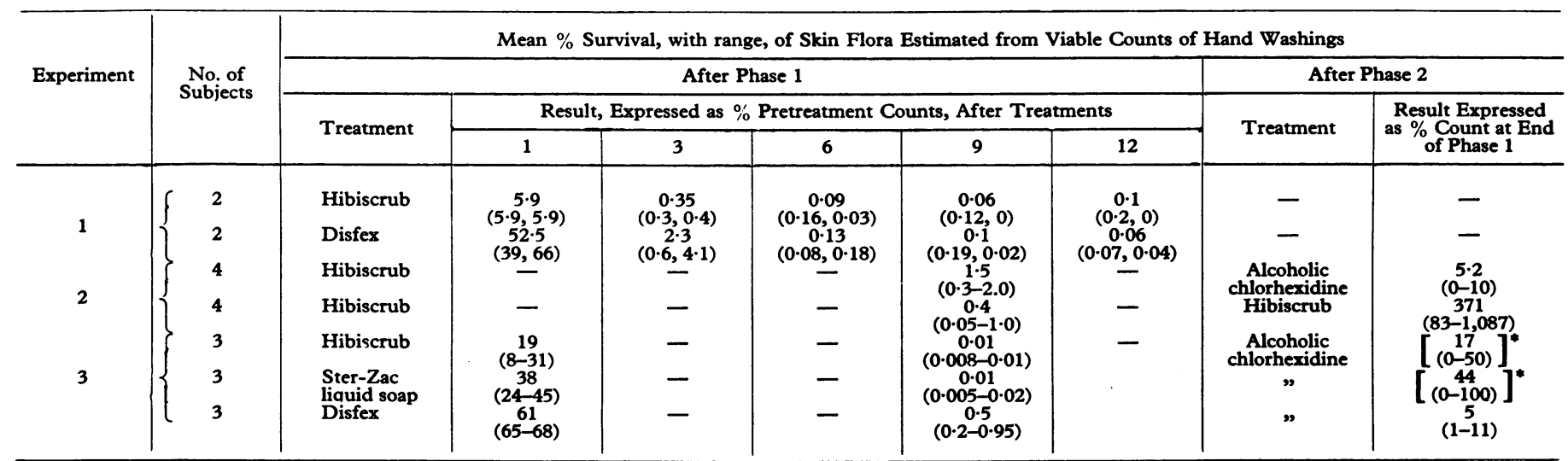


TABLE v-Comparison of $0.3 \%$ Chlorocresol Liquid Soap and $3 \%$ Hexachlorophane Detergent Cream (Disfex): Reduction of Bacterial Counts on Skin Sampling Expressed as Percentage of Initial Count

\begin{tabular}{|c|c|c|c|c|}
\hline \multirow{3}{*}{ Experiments } & \multicolumn{4}{|c|}{ Methods of Disinfection } \\
\hline & \multicolumn{2}{|c|}{$0.3 \%$ Chlorocresol Soap } & \multicolumn{2}{|c|}{$\begin{array}{c}3 \% \text { Hexachlorophane } \\
\text { Detergent Cream (Disfex) }\end{array}$} \\
\hline & 1 Application & 6 Applications & 1 Application & 6 Applications \\
\hline $\begin{array}{l}1 \\
2 \\
3 \\
4 \\
5\end{array}$ & $\begin{array}{ll}\text { B.G. } & 79 \cdot 8 \\
\text { A.K. } & 14 \cdot 3 \\
\text { A.B. } & 18 \cdot 1 \\
\text { B.D. } & 19 \cdot 9 \\
\text { J.B.O. } & 17 \cdot 3\end{array}$ & $\begin{array}{l}90 \cdot 4 \\
27 \\
86 \cdot 1 \\
82 \cdot 2 \\
75 \cdot 5\end{array}$ & $\begin{array}{ll}\text { A.K. } & 58 \cdot 7 \\
\text { J.B.O. } & 44 \cdot 1 \\
\text { B.G. } & 44 \cdot 3 \\
\text { A.B. } & 66 \cdot 4 \\
\text { B.D. } & \mathbf{4 2 \cdot 2}\end{array}$ & $\begin{array}{l}97.5 \\
99.8 \\
99.4 \\
99.8 \\
95.5\end{array}$ \\
\hline $\begin{array}{l}\text { Mean \% } \\
\text { reduction }\end{array}$ & $29.9( \pm 14.9)$ & $72 \cdot 2( \pm 11 \cdot 6)$ & $51 \cdot 1( \pm 4 \cdot 8)$ & $98.4( \pm 0.84)$ \\
\hline
\end{tabular}

Initials indicate experimental subjects

\section{Disinfection of Operation Site with Alcoholic Cetrimide}

In a recent study (Lilly and Lowbury, 1971), aqueous cetrimide $(1 \%)$ used for disinfection of an operation site caused a mean reduction of $55 \%$ in bacterial counts from skin samplings, compared with a $79.6 \%$ reduction after a similar use of $0.5 \%$ chlorhexidine in $70 \%$ ethyl alcohol. The following experiment was made to assess the value of alcoholic cetrimide solution against the natural skin flora. This fills a gap left in our earlier studies, which omitted cetrimide from the series of antiseptics examined for their ability to remove resident flora because of its failure to eliminate transient flora (Lowbury et al., 1960).

\section{EXPERIMENT}

Disinfection of the operation site with $1 \%$ cetrimide in $70 \%$ ethyl alcohol was assessed in comparison with a control treatment (distilled water). Eight experiments, each on a different subject, were made with cetrimide, and similar experiments were made with distilled water on the same eight subjects. The technique of assessment was as in previous studies (Lowbury et al., 1960, 1964b; Lilly and Lowbury, 1971), but slightly modified to prevent effects of carry-over.

The whole surface of both hands was disinfected by systematic and vigorous application of the alcoholic cetrimide solution with a gauze swab soaked in the solution; the application was continued for two minutes, after which the skin was allowed to dry. Bacterial counts were obtained from washings taken immediately before and immediately after the disinfection. The sampling technique was similar to that used in our previous studies, but modified to prevent the effects of carry-over of cetrimide which occurred when the usual technique was used. After the standard sampling in $100 \mathrm{ml}$ of neutralizer solution, $10 \mathrm{ml}$ of the washings were mixed with $10 \mathrm{ml}$ of sterile milk; $1 \mathrm{ml}$ of the mixture was transferred, in $0 \cdot 1-\mathrm{ml}$ amounts, to 10 pour plates of nutrient broth with neutralizers. Viable counts were made after overnight incubation at $37^{\circ} \mathrm{C}$, and tests for carryover were made (Lowbury et al., 1960) on all the pour plates and on a sample of the washings mixed with sterile milk.

\section{RESULTS}

The result of this experiment is shown in table VI. The mean percentage reduction was $69.5 \%$ (range 64.4 to $74.1 \%$ ). This mean reduction was greater than that obtained with aqueous cetrimide in our previous study (Lilly and Lowbury, 1971), but in the same range as that of $70 \%$ ethyl alcohol (Lowbury et al., 1960), and lower than that of $0.5 \%$ chlorhexidine in $70 \%$ ethyl alcohol, which varied between $79.6 \%$ and $84.9 \%$ in three previous studies (Lowbury et al., 1960; 1964b; Lilly and Lowbury, 1971).
TABLE VI-Disinfection of Operation Site: Reduction in Bacterial Counts from Hand Washings as Percentage of Initial Count

\begin{tabular}{|c|c|c|c|c|c|}
\hline \multirow[b]{2}{*}{ Treatment } & \multicolumn{4}{|c|}{ Replicate Experiments } & \multirow{2}{*}{$\begin{array}{c}\text { Mean \% } \\
\text { Reduction }\end{array}$} \\
\hline & 1 & 2 & 3 & 4 & \\
\hline $\begin{array}{l}1 \% \text { Cetrimide } \\
\text { in } 70 \% \\
\text { alcohol } \\
\text { Distilled } \\
\text { water } \\
\text { (Control) }\end{array}$ & $\begin{array}{l}\text { L.M. } 66 \cdot 7 \\
\text { V.R. } 70 \cdot 6 \\
\text { A.K. } \quad 7 \cdot 8 \\
\text { E.R. } \quad 3 \cdot 1\end{array}$ & \begin{tabular}{|rr} 
J.B.O. & $70 \cdot 3$ \\
E.R. & $64 \cdot 4$ \\
V.R. & $11 \cdot 1$ \\
B.D. & $6 \cdot 4$
\end{tabular} & 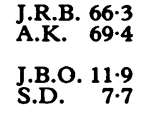 & $\begin{array}{lr}\text { B.D. } & 73.8 \\
\text { S.D. } & \mathbf{7 4 . 1} \\
\text { J.R.B. } & 9 \cdot 5 \\
\text { L.M. } & 7 \cdot 6\end{array}$ & $69 \cdot 5$ \\
\hline
\end{tabular}

Initials indicate experimental subiects.

\section{Residual Action of Hibiscrub}

\section{METHODS}

The following tests (see Lowbury et al., 1964a) were made for residues of antiseptic deposited on the skin after the use of Hibiscrub and Ster-Zac liquid soap. Measured volumes (0.05 $\mathrm{ml}$ ) of suspensions of Staphylococcus aureus and Escherichia coli in Ringer's solution were spread and allowed to dry on the palms of the hands of volunteers who had previously washed their hands for two minutes with Hibiscrub or Ster-Zac, and then rinsed the hands thoroughly and dried them on a sterile towel. After one hour the inoculated area was sampled by a standard sampling technique for superficial "transient" organisms (Story, 1952), and viable counts were obtained from the washings.

\section{RESULTS}

It is shown in table VII that washing with Hibiscrub left a large antibacterial residue on the skin, and this was active against $E$. coli as well as against Staph. aureus. Washing with Ster-Zac liquid soap had a similar residual action against both organisms; the residual action of Ster-Zac against $E$. coli may have been due to the chlorocresol in this preparation, since hexachlorophane has relatively poor activity against Gramnegative bacilli.

TABLE VII-Residual Effects of Hibiscrub and Ster-Zac Liquid Soap

\begin{tabular}{|c|c|c|c|c|}
\hline \multirow{3}{*}{$\begin{array}{l}\text { Preparation Used for } \\
\text { Hand Wash before } \\
\text { applying Bacterial } \\
\text { Suspensions }\end{array}$} & \multicolumn{4}{|c|}{$\begin{array}{l}\text { Mean Viable Counts per ml Washings from } \\
\text { Areas Inoculated with Bacterial Suspensions }\end{array}$} \\
\hline & \multicolumn{2}{|c|}{ Staph. aureus } & \multicolumn{2}{|c|}{ E. coli } \\
\hline & 1 & 2 & 1 & 2 \\
\hline $\begin{array}{l}\text { Hibiscrub } \\
\text { Control (bar soap) }\end{array}$ & $\begin{array}{c}12 \cdot 5 \\
13,500\end{array}$ & $\begin{array}{c}18 \cdot 5 \\
19,500\end{array}$ & $\stackrel{0}{900}$ & $\begin{array}{l}0.25 \\
1,150\end{array}$ \\
\hline $\begin{array}{l}\text { Ster-Zac } \\
\text { Control (bar soap) }\end{array}$ & 24,250 & 19,19 & $\begin{array}{c}15 \\
15,500\end{array}$ & $\begin{array}{c}21 \\
11,000\end{array}$ \\
\hline
\end{tabular}

\section{Discussion}

The new $4 \%$ chlorhexidine detergent preparation, Hibiscrub, was shown in this study to give a significantly greater immediate reduction in resident skin flora after a single two-minutes' hand wash than was obtained after similar use of povidone iodine surgical scrub or of a $0.75 \%$ chlorhexidine detergent preparation (Dermofax). After six successive hand washes spread over two days, however, there was little difference in the reduction of skin flora obtained with these agents and with liquid hexachlorophane detergent preparations, though Hibiscrub had a significantly larger effect than Dermofax. The curve of disinfection on repeated hand washes with any of these preparations shows a steep fall on the first day (steeper with Hibiscrub or povidone iodine than with hexachlorophane preparations), flattening 
after two to three days to an equilibrium level at $1 \%$ or less of the initial levels.

Our earlier studies (Lowbury et al., 1964b) showed that the low counts of skin bacteria reached after six successive treatments with a hexachlorophane detergent cream could be further reduced by disinfection of the same area with alcoholic chlorhexidine rubbed on with gauze ("two-phase" disinfection); this method could be useful in the disinfection of operation sites before elective operations in high-risk patients. These findings were confirmed in the present study, which also showed that two-phase disinfection could be obtained with Hibiscrub as the first-phase detergent preparation. When, however, the hands were washed with Hibiscrub immediately after the ninth of a series of hand washes with the same agent the secondphase treatment failed to cause any further reduction of skin bacteria. This finding parallels that obtained in an earlier study, when hands which had shown a large reduction in bacteria on two-minutes' disinfection with ethyl alcohol failed to show a further reduction on receiving a similar alcohol disinfection immediately afterwards (Lowbury and Lilly, 1960). In some of the experiments few bacteria were found on sampling the skin after the first-phase treatment so that the effect of the second phase could not be shown. The hypothesis that "twophase" disinfection of the skin depends for its effect on the distinct action of two different forms of disinfection was, however, supported by some of these experiments, in which there were differences in the chemistry of the disinfectant used, in the nature of the solvent, and in the mode of application. It is possible that alcohol used in the second phase of disinfection was active against bacteria persisting on the skin through the first phase because they were relatively resistant to chlorhexidine or hexachlorophane.

The other methods which seemed potentially useful for skin disinfection of the operation site of highly susceptible patients gave a somewhat disappointing result. Application for thirty minutes of povidone iodine compresses caused a reduction in the resident flora which was only marginally better than that obtained in a standard two minutes' disinfection with alcoholic iodine or chlorhexidine, and similar treatment with compresses of $0.5 \%$ chlorhexidine gave less satisfactory results. Compresses of povidone iodine provide the most effective method of eliminating bacterial spores on the skin (Lowbury et al., 1964), and when this procedure has been deliberately adopted to reduce hazards of gas gangrene-for example, before amputation of a leg in a patient with arterial insufficiency-the reduction in numbers of vegetative organisms is about the same as that which would be obtained by a standard skin disinfection of the operation site.

A comparison between repeated hand washing with $0.3 \%$ chlorocresol liquid soap and similar treatment with a $3 \%$ hexachlorophane detergent cream showed a larger and more consistent disinfectant action from the hexachlorophane preparation. A large cumulative reduction of skin bacteria was, however, usually caused by the use of chlorocresol soap. It is clearly a much more effective agent for cleaning the skin than ordinary soap, and probably more effective than hexachlorophane bar soap (Lowbury and Lilly, 1960).

These studies have shown that a $4 \%$ chlorhexidine detergent solution is a potentially outstanding addition to the small list of detergent-disinfectant preparations for the hands of surgeons and nurses, with a greater immediate effect than that obtained with the hexachlorophane or even the iodophor preparations. Like Ster-Zac liquid soap and unlike the $0.75 \%$ chlorhexidine detergent preparation previously studied, the $4 \%$ chlorhexidine preparation showed a residual action against bacteria, both Staph. aureus and $E$. coli, deposited on the skin after washing, rinsing, and drying the hands. These properties make Hibiscrub a potentially useful alternative to hexaclorophane detergent preparations for the protection of neonates against staphylococcal infection. Such alternatives are clearly required in the light of possible toxic absorption of hexachlorophane in some infants (Curley et al., 1971), but there appears to be none of proved effectiveness. Hibiscrub, if found safe and effective in infants, would probably have the additional advantage of giving no selective encouragement to Gram-negative infections-a side effect attributed to hexachlorophane (Forfar et al., 1968).

We are grateful to Dr. J. P. Bull for advice and to Mr. M. D. Wilkin for help with statistical assessments; to I.C.I. (Pharmaceuticals) Ltd. for supplies of Hibiscrub and Disadine; to Messrs. Hough-Hoseason for supplies of $0.3 \%$ chlorocresol liquid soap (Ozac), and of Dermofax; and to members of the staff of this unit for their collaboration in tests of skin disinfection.

\section{References}

Collins, B. J., and Deverill, C. E. A. (1971). Pharmaceutical fournal, 206, 369.

Curley, A., Hawk, R. E., Kimbrough, R. D., Nathenson, G., and Finberg, L. (1971). Lancet, 2, 296.

Drewett, S. E., Payne, D. J. H., Tuke, W., and Verdon, P. E. (1972). Lancet, 1, 1172 .

Forfar, J. O., Gould, J. C., and MacCabe, A. F. (1968). Lancet, 2, 177.

Lilly, H. A., and Lowbury, E. J. L. (1971). British Medical fournal, 3, 674.

Lowbury, E. J. L., and Lilly, H. A. (1960). British Medical fournal, $1,1445$.

Lowbury, E. J. L., Lilly, H. A., and Bull, J. P. (1960). British Medical fournal, 2,1039 .

Lowbury, E. J. L., Lilly, H. A., and Bull, J. P. (1963). British Medical Fournal, 1,1251 .

Lowbury, E. J. L., Lilly, H. A., and Bull, J. P. (1964a). British Medical fournal, 2, 230 .

Lowbury, E. J. L., Lilly, H. A., and Bull, J. P. (1964b). British Medical fournal, 2,531 .

Story, P. (1952). British Medical fournal, 2, 1128.
Department of Surgery, University of Khartoum, Sudan

M. A. HASSAN, M.S., F.R.C.S., Senior Lecturer

Radiation and Isotope Centre, Khartoum

E. A. RAHMAN, D.M.R.T., Director

I. A. RAHMAN, B.SC., Physicist incidence of nearly $30 \%$ in $\mathbf{5 4 2}$ patients reported from British hospitals using the same diagnostic technique. The reason for the difference is obscure and needs further investigation.

\section{Introduction}

The incidence of postoperative deep vein thrombosis in patients aged over 40 in British hospitals is from $25-30 \%$. Its incidence in the Sudan and, indeed, throughout Africa is generally believed to be lower than in Western society, but this has not, to our knowledge, been substantiated by proper clinical studies. 